\title{
EVENT OF THE ARCHIVE
}

Mireille Calle-Gruber

The event took place: it was a great moment of explication (Auseinandersetzung) and of truth(s) between Hans-Georg Gadamer, Jacques Derrida, and Philippe Lacoue-Labarthe. ${ }^{1}$ It was transmitted, recorded, photographed, filmed by television (Westdeutscher Rundfunk), and commented on by special correspondents from numerous newspapers. Then retranscribed, corrected by each one of the participants, reread by Derrida, whom Gadamer had asked to review his own interventions. The text of the public debate, and of the meeting with the journalists the following day, was ready. But we agreed, all of us, to defer publication: to wait for tensions to subside, along with the noise of the media's uncontrolable effects.

From that moment, what is reaching us today, twenty-five years later, is the event of the archive-in truth. Which is to say that it is a question of the political (arkbeion designates the house of the archontes that had the function of preserving official documents). More ample than memory, the archive is not turned toward the past: its gesture is inscribed in the present of reading and of writing and is a call for the future-to-come [l'à-venir]. The event of the archive, or that which inaugurates life in its futurity, life-to-come, in truth. That is what the pages that follow give us to think. In this year 2014, when the violences of various nationalisms and extreme right elements are striving, with a certain success, to infiltrate institutions, such a reading of politico-philosophical interrogations is far 
from idle. Likewise for the exemplarity of an ethical will to dialogue and solidarity, despite the divergences that clearly emerged among the three participants.

When the debate between Hans-Georg Gadamer, Jacques Derrida, and Philippe Lacoue-Labarthe was held at the University of Heidelberg, on February 5, 1988, under the official title, "Heidegger: Portée philosophique et politique de sa pensée" (Heidegger: Philosophical and Political Dimensions of his Thought), the context was volatile in every respect. I was able to help bring about this meeting thanks to the friendship of Philippe Lacoue-Labarthe; he made the connection with Derrida, whom I did not yet know, and who agreed immediately, with the inexhaustible generosity that I would continue to find in him. It was also thanks to the confidence shown to me by Gadamer, at the time an emeritus professor who continued to give a very well-attended seminar at the University of Heidelberg. ${ }^{2}$ As for Reiner Wiehl, professor of philosophy at Heidelberg and a former assistant to Gadamer, we had already had occasion to work together, and it was obvious that it would be ideal for him to preside over the session.

The year 1988 was a period of intense polemics. To be sure, these polemics were stoked by the publication in 1987 of the French edition of Victor Farias's book Heidegger and Nazism, a rather simplistic work that garnered much attention in the media. But the polemics had deeper sources, having to do with the political repressed in France: anti-Semitism, collaboration, the Resistance, the crimes of the Vichy regime. This was the period when Robert Faurisson's revisionist theses were on display, as were the negationist statements denying the existence of the extermination camps. The Barbie trial had taken place; there was the "Paul de Man affair" and the appearance of Derrida's book Memoirs for Paul de Man, first in English (Columbia University Press, 1986), then in French in an expanded edition (Galilée, 1988). Philippe Lacoue-Labarthe had just published Heidegger, Art and Politics (La fiction du politique: Heidegger, l'art et la politique [Paris: Bourgois, 1987]), which included 
an appendix, "On Victor Farias' Book," and Jean-Luc Nancy published The Inoperative Community (La communauté désoeuvrée [Paris: Bourgois 1986, 1988]), which elaborated an analysis of the process of "mythation" in the West; this came after the work coauthored by Nancy and Lacoue-Labarthe on "The Nazi Myth" first presented at Schiltigheim for a colloquium on "The Mechanisms of Fascism," organized in 1980 by the "Comité d'information sur l'holocauste." Their analyses studied the way in which, at the heart of the political and social practice of Nazism, myth was set to work as an identitary figure leading to the fashioning of a people according to a supposed Germano-Aryan autochthony, and how the Nazi horror was based on a "national aestheticism"-a term thus designating, as Lacoue-Labarthe specified in Heidegger, Art and Politics, the symptom of the "aborted Modern"-within a modern politics that, far from acceding to the modern, remained subjected to the imitatio of the ancient, to the "Greek model."

In addition, while not exactly polemical, the encounter that had taken place a few years earlier between Gadamer and Derrida-in the context of the colloquium "Texte et interprétation" organized by Philippe Forget at the Goethe Institute in Paris (April 25-27, 1981)-had quickly become contentious, and the two philosophers found themselves at odds with one another. Whereas Gadamer, following the hermeneutic approach, pursued a philosophical thought of continuity and articulation, Derrida was already proceeding along the path of interruption, an attempt to "give to read the interruption that in any case will decide the figure itself," ${ }^{4}$ according to an approach whose formulation-"I must teach you how to teach me how to read myself"-soon stood as a counterpoint to Gadamer's "understanding." And Derrida, with "Good Will to Power," offered a "Response to Hans-Georg Gadamer," who for his part titled his "Response to Jacques Derrida": "And Yet: Power of Good Will." With this debate in Heidelberg, one might anticipate that these tensions would hardly be calmed by the presence of Lacoue-Labarthe, this thinker who, with great urgency, sought to expose "the historial 
caesura of our time" that Auschwitz represents, ${ }^{6}$ and the discordant temporality of a humanity henceforth "caesura-ed" ("what follows the caesura will never be the same as what went before; the end will never again resemble the beginning"); ${ }^{7}$ at the same time, Gadamer opened the proceedings by insisting on the "task of communicating," which he considered a philosophical imperative, and he made it a point to take up the dialogue beginning from the impasse where they had left off in $1981{ }^{8}$

This is to say that, on February 5, 1988, a reflection on the philosophical and political dimensions of Heidegger's thought had become a very current and pressing matter. To this was added the fact that it was in the very lecture hall where Heidegger, in 1933, as rector of the University of Freiburg, had given the speech on "The University in the New Reich" that this debate was to take place, before more than a thousand students and professors who were summoned to their responsibility to think thinking.

The encounter of 1988 was no doubt rendered historic by the kairos of this moment, in which the magnitude of the participants rose to the level of the situation of crisis touching directly on the task of thought. But above all, this encounter is important at present, in our present, because of the lesson that it offers concerning the political and ethical stakes that traverse our existences: allowing us to rework a past that continues to make demands on us and whose unsaid elements burden the future, and to elaborate, in the order of events, the emergence of a thought capable, perhaps, of thinking an always fragile democracy.

That is why we must be careful here not to hypostasize the scene, still less to sacralize it; it must come to us anew, enlivened by its ambivalences and uncertainties: the event in its multiple echoes, in the trembling of its becoming.

In this year of 2014, our vigilance can only increase, given the publication of the first three volumes of the Heidegger's Scbwarze Hefte. ${ }^{9}$ Not that one must interpret the Heidelberg conference on 
the basis of these "black notebooks," whose existence was unknown to everyone at the time; to do so would falsely distort the 1988 debate. But the Schwarze Hefte that Heidegger kept from the early 1930s until the beginning of the 1970s, in parallel to his published works, promise to shed light on the divergences that appear, at the darkest moment of German history in the twentieth century, between the public works and these working notes, which the philosopher held back for a much later publication, as the concluding moment of his complete works, the Gesamtausgabe.

The Schwarze Hefte revive the question of the anti-Semitism that has been attributed to Heidegger. At the time of the Heidelberg conference, this consisted only of one isolated incident related by Karl Jaspers, concerning an anti-Semitic remark made during a private conversation in May 1933, that had no echo in Heidegger's published works. ${ }^{10}$ Now Peter Trawny, the editor of the Scbwarze Hefte, speaks of a "historial anti-Semitism" ("seinsgeschichtlicher Antisemitismus") in reference to certain passages of the notebooks. ${ }^{11}$

In that light, Derrida's position in 1988, calling for a "polemical relation" of "counter-questioning" with regard to Heidegger, will no doubt be more necessary than ever, so as not to hastily conclude the debate by reducing Heidegger to an ordinary Nazi, or even to a meta-Nazi. As it stands, any critical reading of these new documents would have to define what they contain in terms of anti-Semitic remarks, but also in terms of the ambivalences in their formulations, or else to establish the distinction made there between "vulgar National Socialism" and "spiritual national Socialism," while also taking account of the deconstructive argumentation that Heidegger brings to the question of being in general (which he crosses out), and on the forms of Christian and Jewish monotheism in particular, considered as strategies of domination (his anticlerical position is well known). ${ }^{12}$ The task of critique today, then, is to pose questions precisely where Heidegger's questioning failed-that is, to take up questions at the place where Heidegger's thought re- 
mained incomplete, in the hiatus in which his ethical failure is inscribed, his unforgivable silence regarding Auschwitz. It is this place that all the protagonists of the Heidelberg debate designate as the point where they must exercise their responsibility-which is to say, ours, as Jean-Luc Nancy rightly reminds us in his note from 2014 which serves as the Foreword to this book.

When Gadamer died on March 13, 2002, at the age of 102, Derrida wrote a text that was much more than a circumstantial homage: "I do not believe in the death of Gadamer. I cannot bring myself to believe in it. I had gotten used to the idea that Gadamer would never die, that he was not a man who could die.... I envied him his capacity to affirm life. It seemed invincible. I was convinced that someone like Gadamer deserved never to die, because we needed such an absolute witness, who participated actively or as an observer in all the philosophical debates of the century." 13 Aside from being a beautiful salute to life, which was not so customary for him, Derrida also underscored the unconditional respect they had always shared, despite the gulf separating their interpretations of interpretation, and stressed that there was "no danger that war, contempt or insult"14 would ever disturb what bound them across such a distance.

That is indeed what one hears in the Heidelberg encounter, beyond the misunderstandings and impasses: the certainty, and the promise, of a respect owed to the exigency of thought. Gadamer and Derrida, and Lacoue-Labarthe with them, affirm in what follows the injunction placed on their responsibility "before the necessity of reading Heidegger as he did not read himself." 15

But there is more. For in this posthumous address we see that Derrida, performing the same gesture made by Gadamer in Heidelberg, speaks here again beginning from their disagreement in 1981. And he cites the text with which his interlocutor had replied ("And yet: the power of good will"), as if it had made its way to him, finally audible, by approaching a certain process of depropriation: 
Every reading that seeks understanding is only a step on a path that never ends. Whoever sets out on this path knows that he or she will never be completely done with the text: one accepts the blow, the thrust, that the text delivers. The fact that a poetic text can so touch someone that one ends up "entering" into it and recognizing oneself in it, assumes neither harmonious agreement nor self-confirmation. One must lose oneself in order to find oneself. I believe I am not very far from Derrida, when I stress that one never knows in advance what one will find oneself to be. ${ }^{16}$

One year later, on February 15, 2003, ${ }^{17}$ during a lecture given by Derrida in memory of Gadamer, once again in Heidelberg, it was in the reading of a poem that he found the promise of encounter. I am referring to "Rams," with its subtitle that gestures toward Gadamer: "Uninterrupted Dialogue-Between Two Infinities, the Poem." 18 The poem is by Paul Celan ("Grosse, glühende Wölbung," in Atemwende), in which one verse in particular calls for interpretation: "Die Welt is fort, ich muss dich tragen," "The world is gone, I must carry you." ${ }^{19}$ Here it is a question of the task of "carrying the other," of the need to carry him, "to carry without appropriating." "20 "And I only am, I can only be, I must only be starting from this strange, dislocated bearing of the infinitely other in me." ${ }^{21}$ And it is indeed in the relation to the poem that the two philosophers echo one another: for in the end Gadamer was always attentive to the question of translation as poetic experience ${ }^{22}$ and considered poetry as "the great instance for the experience of the ownness and foreignness of language." 23

During the evening of the debate on Heidegger, on February 5 , 1988, the encounter took place under the sign of hospitality: a hospitality in the French language, offered by Gadamer to his guests. Thus were all three of them strangers and foreigners, Derrida and Lacoue-Labarthe in Germany, Gadamer in the French language, and all three were "others" in depropriation and in the need to "carry the other." The force of this dialogue on the edge of the abyss and in 
an awareness of the untranslatable is also, for us today, a precious lesson. It obliges us to rework questions that remain urgently open, incessantly reemerging in the languages of writing-thinking. And to implicate ourselves.

After Jacques Derrida's death on October 9, 2004, but just before the collection published in Montreal was to appear the following year, Jean Grondin carried out a symbolic gesture of philosophy's infinite conversation: he translated Derrida's German text into French ("Comme il avait raison! Mon Cicérone Hans-Georg Gadamer") and placed it in that collection, thus giving a supplementary turn of the screw. Between two infinities, interrupting the interruption. Philippe Lacoue-Labarthe died on January 28, 2007, in Paris. Reiner Wiehl, with whom we were planning to publish the present volume, died in Heidelberg on December 30, 2010, a few weeks after sending me the text of his preface. My gratitude goes out to Andrea Gadamer, to Marguerite Derrida, and to Claire Lacoue-Labarthe, who authorized this publication. ${ }^{24}$

To make known today the words of these three philosophers, their texts, their exemplary effort of justice and of precision [justesse] takes on a singular weight. The works remain vigilant; they help us to discern events in truth. They remind us that "we no longer live in the dimension or in the logic of the origin. We exist in belatedness, in a historical after-effect [l'après-coup]. Which does not mean that the extremity of the belated is not also the emergence of the new. It is even precisely this that we are required to think." 25 These words of Philippe Lacoue-Labarthe and Jean-Luc Nancy open the threshold of "The Nazi Myth." They are more than ever a part of our actuality.

The injunction addressed to us today by the Heidelberg conference is exorbitant: to strive to read Heidegger as he did not read himself-that is, rather than limiting ourselves to condemning him, to make it such that his silence on Auschwitz carries us toward the difficult courage of thinking. 
HEIDEGGER,

PHILOSOPHY,

AND POLITICS 


$\begin{array}{ccc}\text { Jacques } & \text { Hans-Georg } & \text { Philippe } \\ \text { DERRIDA } & \text { GADAMER } & \text { LACOUE-LABARTHE } \\ \text { (Paris) } & \text { (Heidelberg) } & \text { (Strasbourg) }\end{array}$

discutent sur

HEIDEGGER

PORTEE PHILOSOPHIQUE ET POLITIQUE

DE SA PENSEE

Président de séance:

Reiner WIEHL (Heidelberg)

Vendredi 5 février 1988,

Informations

20 Uhr c.t., Hörsaal 13,

Institut Français

Neue Universität, Heidelberg

SeminarstraBe 3

La discussion se déroulera

6900 Heidelberg

en français

Présentation: Mireille Calle-Gruber

tél. $06221 / 25288$

\title{
Philosophisches Seminar
}

et

\author{
Institut Français \\ Heidelberg
}

IN VITATION 